\title{
The Structure and Growth of a Titus Phase Community Cemetery in Titus County, Texas
}

Timothy K. Perttula

Heritage Research Center, Stephen F. Austin State University

Follow this and additional works at: https://scholarworks.sfasu.edu/ita

Part of the American Material Culture Commons, Archaeological Anthropology Commons, Environmental Studies Commons, Other American Studies Commons, Other Arts and Humanities Commons, Other History of Art, Architecture, and Archaeology Commons, and the United States History Commons

Tell us how this article helped you.

This Article is brought to you for free and open access by the Center for Regional Heritage Research at SFA ScholarWorks. It has been accepted for inclusion in Index of Texas Archaeology: Open Access Gray Literature from the Lone Star State by an authorized editor of SFA ScholarWorks. For more information, please contact cdsscholarworks@sfasu.edu. 
The Structure and Growth of a Titus Phase Community Cemetery in Titus County, Texas

\section{Creative Commons License}

\section{(c) (1) (8)}

This work is licensed under a Creative Commons Attribution-NonCommercial 4.0 International License 


\section{The Structure and Growth of a Titus Phase Community Cemetery in Titus County, Texas}

\section{Timothy K. Perttula}

The W-S site (41TT741) is a large post-A.D. 1600 Titus phase cemetery on Swauano Creek in the Big Cypress Creek basin (Perttula 2005: Figure 11-11). The site was dug in the late 1970 s by Ralph Nicholas and associates, and there are available notes and maps on his excavations on file at the Texas Archeological Research Laboratory at The University of Texas at Austin. Here I employ these notes and maps to examine the structure and growth of this particular Caddo community cemetery.

The notes indicate that there were 118 individual burials in the cemetery (Figure 1). The funerary objects placed with the burials included 837 vessels ( 7.09 vessels per burial), 483 arrow points ( 4.09 points per burial), six ceramic pipes, 26 ground stonc celts, five marine shell beads, five ceramic or bone ear spools, and five large chipped stone bifaces (Table 1). As a whole, there is a mean of 11.59 funerary objects per individual burial, and a total of 1367 funerary objects from the entire cemetery. This mean number is very much consistent with the kinds and quantities of funerary objects placed with individual burials from other Titus phase cemeteries (Perttula 2005: Table 11-6).

Table 1. Funerary Objects in the W-S Cemetery.

\begin{tabular}{|c|c|c|c|c|c|c|c|c|c|}
\hline $\begin{array}{l}\text { Cemetery } \\
\text { Phase }\end{array}$ & $\begin{array}{l}\text { Burial } \\
\text { No. }\end{array}$ & $\begin{array}{l}\text { Ceramic } \\
\text { Vessels }\end{array}$ & Pipes & $\begin{array}{l}\text { Arrow } \\
\text { points }\end{array}$ & Celts & Beads & $\begin{array}{l}\text { Ear } \\
\text { Spool }\end{array}$ & Blades & $\mathrm{N}$ \\
\hline
\end{tabular}

Phase 1

$\begin{array}{lllllllll}10 & 7 & - & 7 & - & - & - & - & 14 \\ 11 & 12 & - & 3 & - & - & - & - & 15 \\ 12 & 5 & - & 2 & - & - & - & - & 7 \\ 14 & 8 & - & - & 2 & - & - & - & 10 \\ 15 & 7 & - & 3 & - & - & - & - & 10 \\ 16 & 11 & - & 13 & - & 5 & 1 & - & 30 \\ 93 & 11 & - & 8 & 1 & - & - & 1 & 21 \\ 95 & 9 & - & - & - & - & - & - & 9 \\ 101 & 7 & - & - & - & - & - & - & 7 \\ 103 & 6 & - & - & - & - & - & - & 6 \\ 104 & 4 & - & - & - & - & - & - & 4 \\ 112 & 1 & - & - & - & - & - & - & 1 \\ 115 & 1 & - & - & - & - & - & - & 1\end{array}$

Phase 2

$\begin{array}{lllllllll}1 & 14 & - & 13 & 1 & - & - & - & 28 \\ 2 & 10 & - & 8 & - & - & - & - & 18 \\ 3 & 8 & - & 11 & - & - & - & - & 19 \\ 4 & 14 & - & 2 & - & - & - & - & 16 \\ 5 & 4 & - & - & - & - & - & - & 4\end{array}$




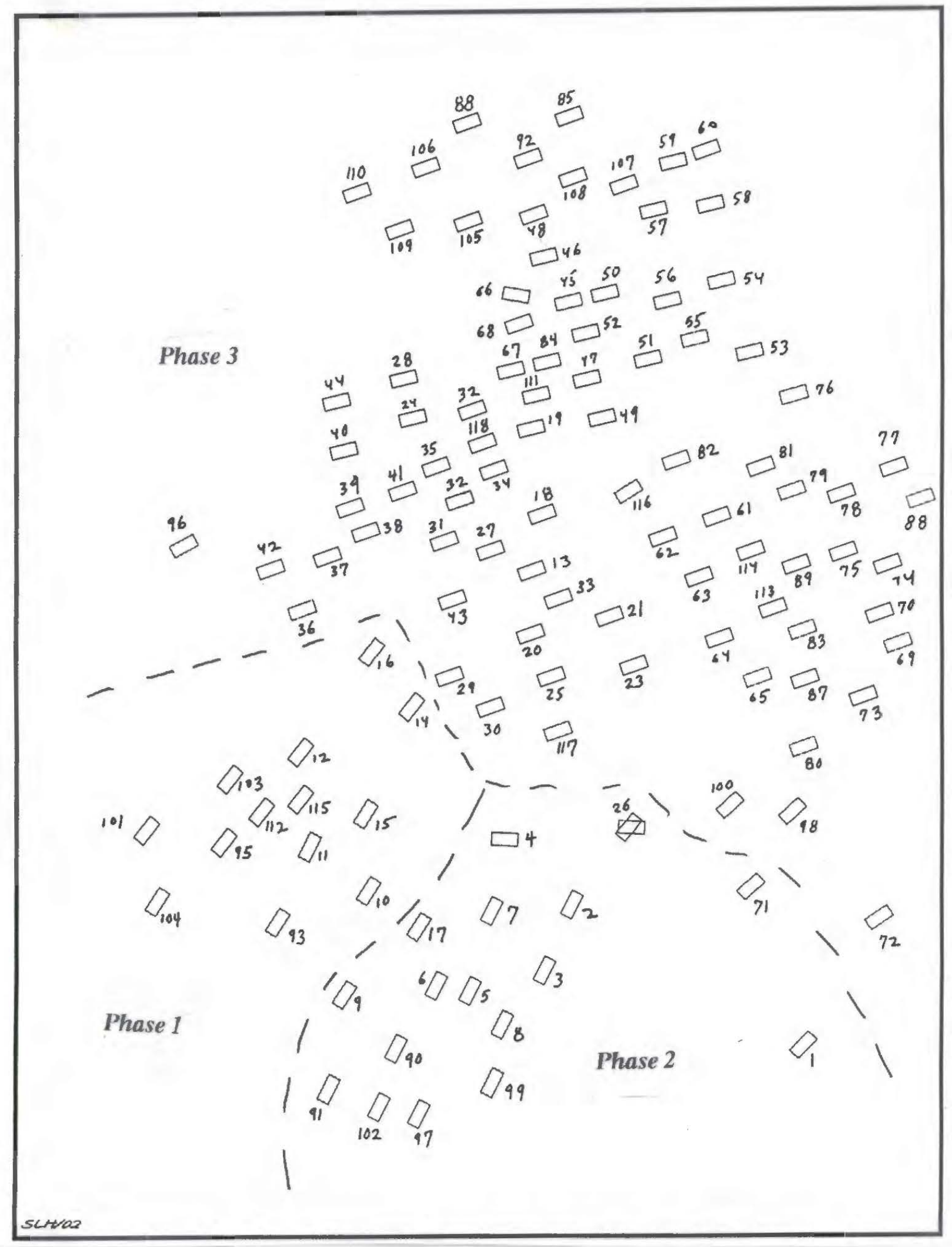

Figure 1. Plan of the W-S Cemetery site (41TT741) and Phase 1-3 cemetery areas. 
Journal of Northeast Texas Archaeology, No. 25 (2006)

Table 1. Funerary Objects in the W-S Cemetery, cont.

\begin{tabular}{llllllllll}
\hline $\begin{array}{l}\text { Cemetery } \\
\text { Phase }\end{array}$ & $\begin{array}{l}\text { Burial } \\
\text { No. }\end{array}$ & $\begin{array}{l}\text { Ceramic } \\
\text { Vessels }\end{array}$ & Pipes & $\begin{array}{l}\text { Arrow } \\
\text { points }\end{array}$ & Celts & Beads & $\begin{array}{l}\text { Ear } \\
\text { Spool }\end{array}$ & Blades & N \\
\hline $\begin{array}{lllllllll}\text { Phase 2, } \\
\text { cont. }\end{array}$ & 6 & 15 & - & 2 & - & - & - & - & 17 \\
& 7 & 4 & - & 1 & - & - & - & - & 5 \\
& 8 & 10 & 1 & 30 & 1 & - & - & - & 42 \\
& 9 & 11 & - & 1 & - & - & - & - & 12 \\
& 17 & 12 & - & 1 & - & - & - & - & 13 \\
& 26 & 13 & - & 37 & - & - & - & - & 50 \\
& 71 & 8 & - & 30 & - & - & - & - & 38 \\
& 90 & 15 & - & 11 & 1 & - & - & 3 & 30 \\
& 91 & 6 & - & 1 & - & - & - & - & 7 \\
& 97 & 6 & - & - & - & - & - & - & 6 \\
& 102 & 11 & & - & - & - & - & - & 11
\end{tabular}

Phase 3

$\begin{array}{lllllllll}13 & 8 & - & - & 2 & - & - & - & 10 \\ 18 & 8 & - & 1 & - & - & - & - & 9 \\ 19 & 8 & - & 3 & - & - & - & - & 11 \\ 20 & 11 & - & 1 & 1 & - & - & - & 13 \\ 21 & 11 & - & 3 & - & - & - & - & 14 \\ 22 & 12 & - & 4 & 1 & - & - & - & 17 \\ 23 & 10 & - & 1 & - & - & - & - & 11 \\ 24 & 9 & - & - & 1 & - & - & - & 10 \\ 25 & 7 & - & 4 & - & - & - & - & 11 \\ 27 & 8 & - & 8 & 2 & - & - & - & 18 \\ 28 & 5 & - & - & 1 & - & - & - & 6 \\ 29 & 1 & - & 6 & - & - & - & - & 7 \\ 30 & 3 & - & - & - & - & - & - & 3 \\ 31 & 11 & - & 14 & 1 & - & - & - & 26 \\ 32 & 4 & - & 2 & - & - & - & - & 6 \\ 33 & 5 & - & 10 & - & - & - & - & 15 \\ 34 & 5 & - & - & - & - & - & - & 5 \\ 35 & 3 & - & - & - & - & - & - & 3 \\ 36 & 5 & - & 17 & - & - & - & - & 22 \\ 37 & 8 & - & - & - & - & - & - & 8 \\ 38 & 5 & - & - & - & - & - & - & 5 \\ 39 & 8 & 1 & - & - & - & - & - & 9 \\ 40 & 7 & - & - & - & - & - & - & 7 \\ 41 & 4 & - & - & - & - & - & - & 4 \\ 42 & 6 & - & - & - & - & - & - & 6 \\ 43 & 8 & - & - & - & - & - & - & 8 \\ 44 & 7 & 2 & - & - & - & - & - & 9 \\ 45 & 7 & - & 7 & - & - & - & - & 14 \\ 46 & 10 & - & 6 & - & - & - & - & 16 \\ 47 & 10 & 1 & 30 & 4 & - & 4 & - & 49 \\ 48 & 4 & - & - & - & - & - & - & 4 \\ 49 & 7 & - & - & - & - & - & - & 7 \\ 50 & 8 & - & - & - & - & - & - & 8 \\ 51 & 8 & - & 5 & - & - & - & - & 13 \\ 52 & 6 & - & - & - & - & - & - & 6\end{array}$


Table 1. Funerary Objects in the W-S Cemetery, cont.

\begin{tabular}{|c|c|c|c|c|c|c|c|c|c|}
\hline $\begin{array}{l}\text { Cemetery } \\
\text { Phase }\end{array}$ & $\begin{array}{l}\text { Burial } \\
\text { No. }\end{array}$ & $\begin{array}{l}\text { Ceramic } \\
\text { Vessels }\end{array}$ & Pipes & $\begin{array}{l}\text { Arrow } \\
\text { points }\end{array}$ & Celts & Beads & $\begin{array}{l}\text { Ear } \\
\text { Spool }\end{array}$ & Blades & $\mathbf{N}$ \\
\hline Phase 3 & 53 & 4 & - & 1 & - & - & - & - & 5 \\
\hline \multirow[t]{47}{*}{ cont. } & 54 & 8 & - & - & - & - & - & - & 8 \\
\hline & 55 & 4 & - & 12 & - & - & - & - & 16 \\
\hline & 56 & 8 & - & 7 & 2 & - & - & - & 17 \\
\hline & 57 & 9 & - & 8 & - & - & - & - & 17 \\
\hline & 58 & 8 & - & 2 & - & - & - & - & 10 \\
\hline & 59 & 3 & - & - & - & - & - & - & 3 \\
\hline & 60 & 3 & - & - & - & - & - & - & 3 \\
\hline & 61 & 11 & - & - & - & - & - & - & 11 \\
\hline & 62 & 11 & - & 12 & - & - & - & 1 & 24 \\
\hline & 63 & 5 & 1 & 7 & 1 & - & - & - & 14 \\
\hline & 64 & 4 & - & 6 & - & - & - & - & 10 \\
\hline & 65 & 5 & - & - & - & - & - & - & 5 \\
\hline & 66 & 6 & - & - & - & - & - & - & 6 \\
\hline & 67 & 4 & - & - & - & - & - & - & 4 \\
\hline & 68 & 6 & - & - & - & - & - & - & 6 \\
\hline & 69 & 7 & - & 1 & - & - & - & - & 8 \\
\hline & 70 & 8 & - & 3 & - & - & - & - & 11 \\
\hline & 72 & 8 & - & 8 & - & - & - & - & 16 \\
\hline & 73 & 11 & - & - & - & - & - & - & 11 \\
\hline & 74 & 9 & - & 26 & 1 & - & - & - & 36 \\
\hline & 75 & 3 & - & 2 & - & - & - & - & 5 \\
\hline & 76 & 4 & - & - & - & - & - & - & 4 \\
\hline & 77 & 5 & - & 1 & - & - & - & - & 6 \\
\hline & 78 & 4 & - & - & - & - & - & - & 4 \\
\hline & 79 & 6 & - & 24 & - & - & - & - & 30 \\
\hline & 80 & 10 & - & 12 & - & - & - & - & 22 \\
\hline & 81 & 1 & - & - & - & - & - & - & 1 \\
\hline & 82 & 4 & - & - & - & - & - & - & 4 \\
\hline & 83 & 6 & - & 24 & 1 & - & - & - & 31 \\
\hline & 84 & 5 & - & 1 & - & - & - & - & 6 \\
\hline & 85 & 10 & - & 4 & - & - & - & - & 14 \\
\hline & 86 & 3 & - & - & - & - & - & - & 3 \\
\hline & 87 & 1 & - & 4 & - & - & - & - & 5 \\
\hline & 88 & 8 & - & - & - & - & - & - & 8 \\
\hline & 89 & 8 & - & 1 & - & - & - & - & 9 \\
\hline & 92 & 7 & - & - & - & - & - & - & 7 \\
\hline & 94 & 5 & - & - & - & - & - & - & 5 \\
\hline & 96 & 6 & - & 4 & - & - & - & - & 10 \\
\hline & 98 & 8 & - & 1 & - & - & - & - & 9 \\
\hline & 99 & 9 & - & - & - & - & - & - & 9 \\
\hline & 100 & 6 & - & - & - & - & - & - & 6 \\
\hline & 105 & 8 & - & 3 & 2 & - & - & - & 13 \\
\hline & 106 & 4 & - & - & - & - & - & - & 4 \\
\hline & 107 & 2 & - & - & - & - & - & - & 2 \\
\hline & 108 & 5 & - & - & - & - & - & - & 5 \\
\hline & 109 & 6 & - & - & - & - & - & - & 6 \\
\hline & 110 & 7 & - & - & - & - & - & - & 7 \\
\hline
\end{tabular}


Table 1. Funerary Objects in the W-S Cemetery, cont.

\begin{tabular}{llllllllll}
\hline $\begin{array}{l}\text { Cemetery } \\
\text { Phase }\end{array}$ & $\begin{array}{l}\text { Burial } \\
\text { No. }\end{array}$ & $\begin{array}{l}\text { Ceramic } \\
\text { Vessels }\end{array}$ & Pipes & $\begin{array}{l}\text { Arrow } \\
\text { points }\end{array}$ & Celts & Beads & $\begin{array}{l}\text { Ear } \\
\text { Spool }\end{array}$ & Blades N & \\
\hline $\begin{array}{llllllllll}\text { Phase 3 } \\
\text { cont. }\end{array}$ & 111 & 3 & - & - & - & - & - & - & 3 \\
& 113 & 5 & - & - & - & - & - & - & 5 \\
& 114 & 4 & - & - & - & - & - & - & 4 \\
& 116 & 3 & - & - & - & - & - & - & 3 \\
& 117 & 12 & - & 4 & - & - & - & - & 16 \\
\hline
\end{tabular}

Based on the sketches of vessels $(\mathrm{n}=317)$ found with the burials excavated and recorded in more detail by Nicholas, the majority of the ceramic vessels were carinated bowls (Table 2 and Figure 2). They account for $44.8 \%$ of this sample. Bottles and ollas comprise $12 \%$ of the vessel funerary offerings, and more than $32 \%$ are cooking jars of various sizes. The remainder are simple bowls, one effigy vessel, and two small ceramic pigment vessels.

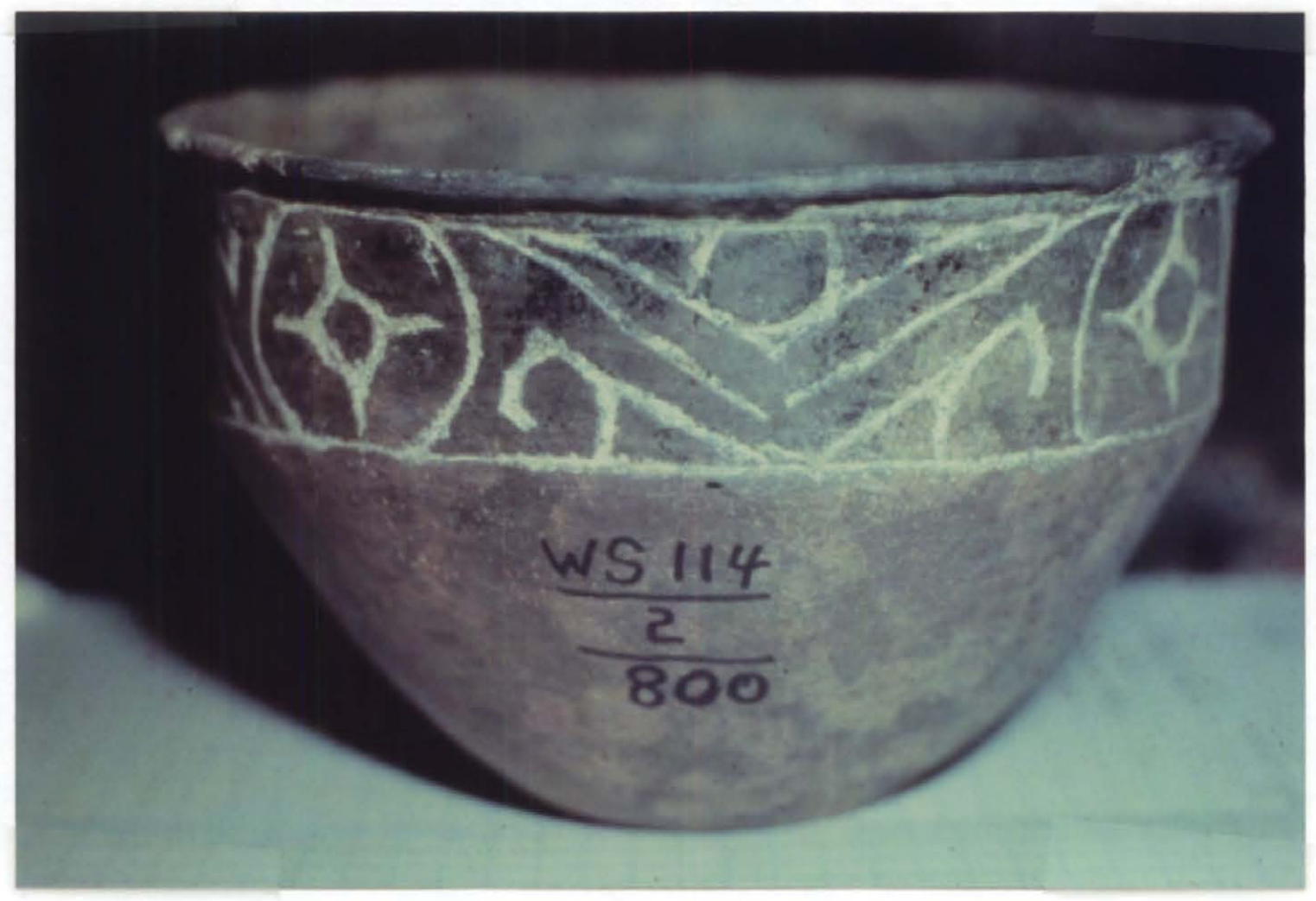

Figure 2. Engraved carinated bowl from Burial 114 at the W-S site. 
Table 2. Identifiable Vessel Forms in the W-S Cemetery (41TT741)

\begin{tabular}{lll}
\hline Vessel Form & No. & Percent \\
\hline Carinated bowl & 142 & 44.8 \\
Compound bowl & 21 & 6.7 \\
Double bowl & 1 & 0.3 \\
Peaked rim bowl & 1 & 0.3 \\
Simple conical bowl & 8 & 2.5 \\
Globular bowl & 1 & 0.3 \\
Bottle & 28 & 8.8 \\
Compound bottle & 3 & 1.0 \\
Olla & 7 & 2.2 \\
& & 11.3 \\
Large jar & 36 & 18.6 \\
Medium jar & 59 & 2.2 \\
Small jar & 7 & 0.3 \\
Effigy vessel & 1 & 0.6 \\
Pigment vessel & 2 & 100.0 \\
\hline \multirow{2}{\text{Total}}{} & & \\
\hline
\end{tabular}

In looking at the orientation and spacing of the burials (see Figure 1) and the various burial rows within the cemetery, the W-S cemetery may have been used at three different (and probably sequent) periods of time. The burials from each period do not overlap, with one apparent and notable exception (Burial 26) in the central part of the cemetery itself (see Figure 1). Information on the range and kind of funerary offerings from the three different periods of cemetery use (Phase 1-3) shed some light on differences in mortuary ritual at a large Titus phase community cemetery.

First, the earliest burials (Phase 1 and 2) in the southern part of the W-S cemetery tended to have more ceramic vessels and caches of Talco arrow points (Figure 3 ) than did the larger and later northern part of the cemetery (Phase 3 ). This is particularly the case in the Phase 2 cemetery as four different burials $(1,4,6$, and 90$)$ each had more than 14 vessels placed as offerings with the deceased. None of the Phase 1 or 3 burials had that many vessel offerings. Three other Phase 2 burials $(8,26$, and 71$)$ each had more than 30 Talco arrow points in individual graves compared to only one burial (47) in the northern part of the cemetery (Figure 4). Talco arrow points themselves are found in many graves in the youngest Phase 3 part of the cemetery, but they did not generally occur in large caches, 
except for three burials $(74,79$, and 83$)$ in the eastern part of the Phase 3 cemetery (Figure 5).

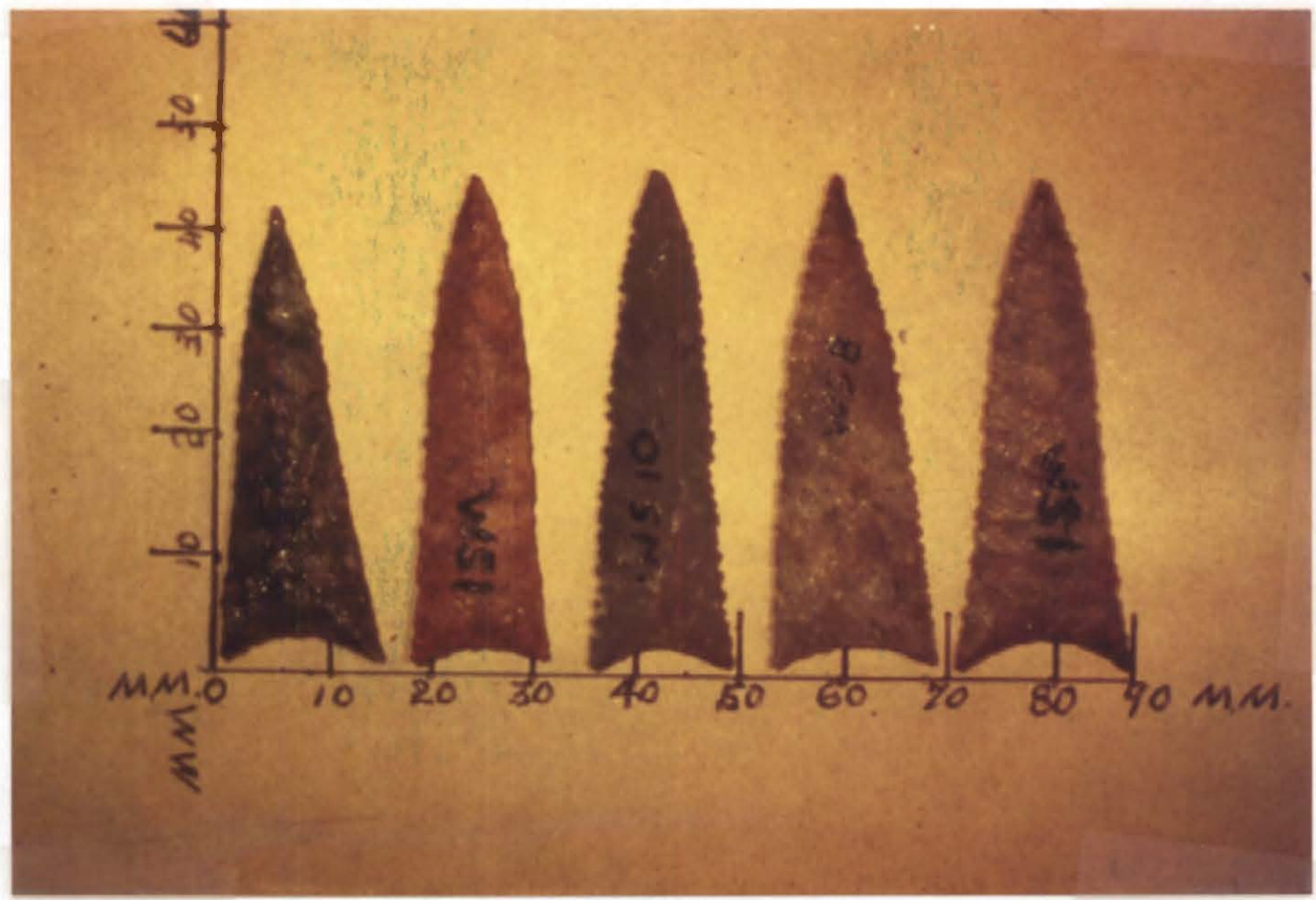

Figure 3. Talco arrow points from the W-S cemetery.

The one burial with marine shell beads (Figure 6) and ceramic car spools is also found in the Phase 1 cemetery area (Figure 7). The only other burial with ear spools is in the Phase 3 cemetery (47). Six burials have clay elbow pipes (Figure 8) as funerary offerings. Sixty-seven percent of them are in the northern (Phase 3 ) cemetery area (Figure 9).

Four burials $(55,62,74$, and 90$)$ had large chipped stone blades (see Figure 9), probably Galt bifaces (cf. Thurmond 1990). Three of these are in the northern and youngest cemetery area. Celts were funerary offerings almost exclusively found in the Phase 3 cemetery area, with limited use of this ground stone tool in the Phase 1 and 2 cemetery areas (Figure 10).

The best indication of the temporal differences between the burials from the different parts of the W-S community cemetery is the occurrence of certain engraved fine ware pottery vessels in burials. Ripley Engraved vessels with the pendant triangle 


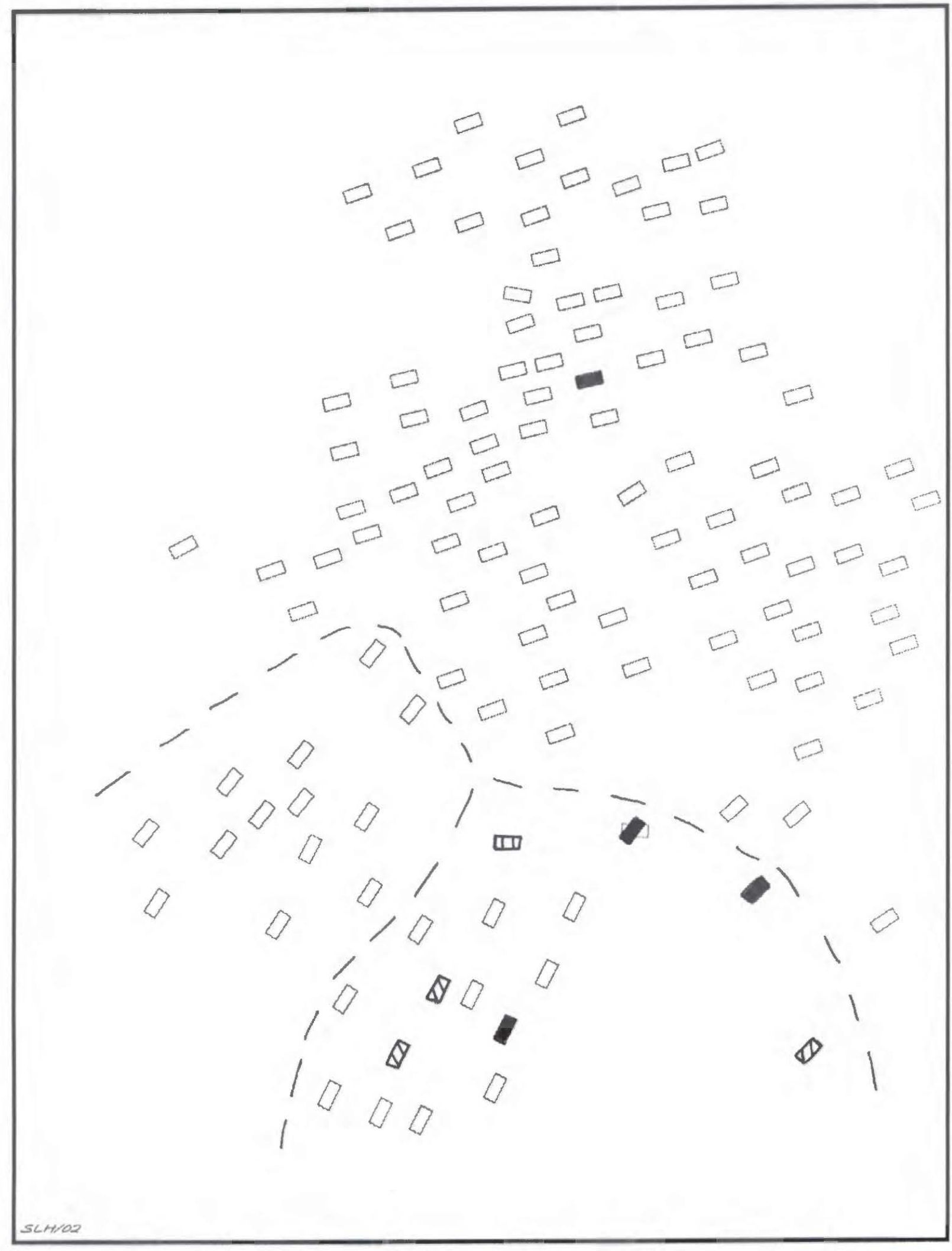

Figure 4. Burials with more than 30 arrow points (solid black graves) and burials with high numbers of ceramic vessels (hatched graves). 


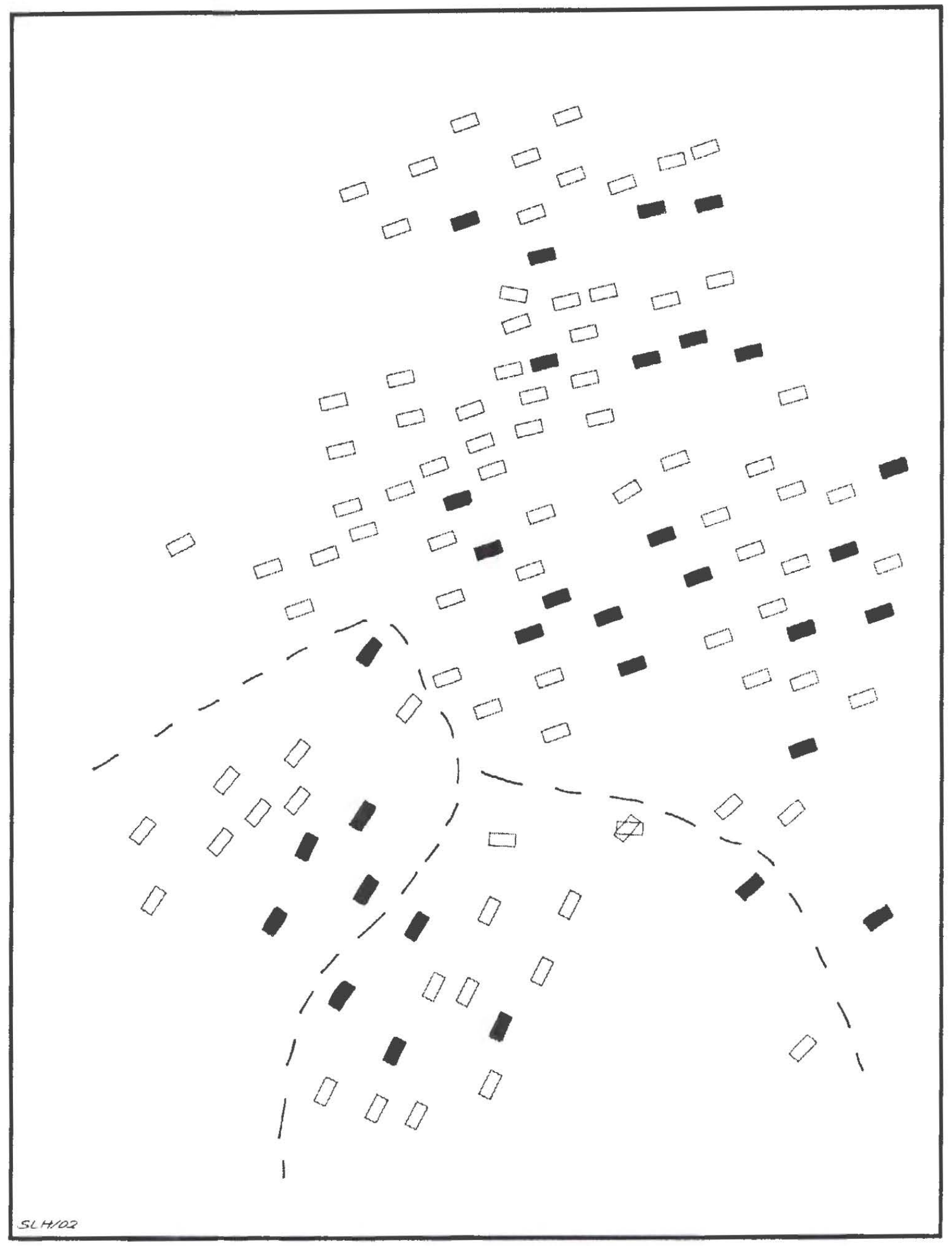

Figure 5. Burials with Talco arrow points (solid black graves). 


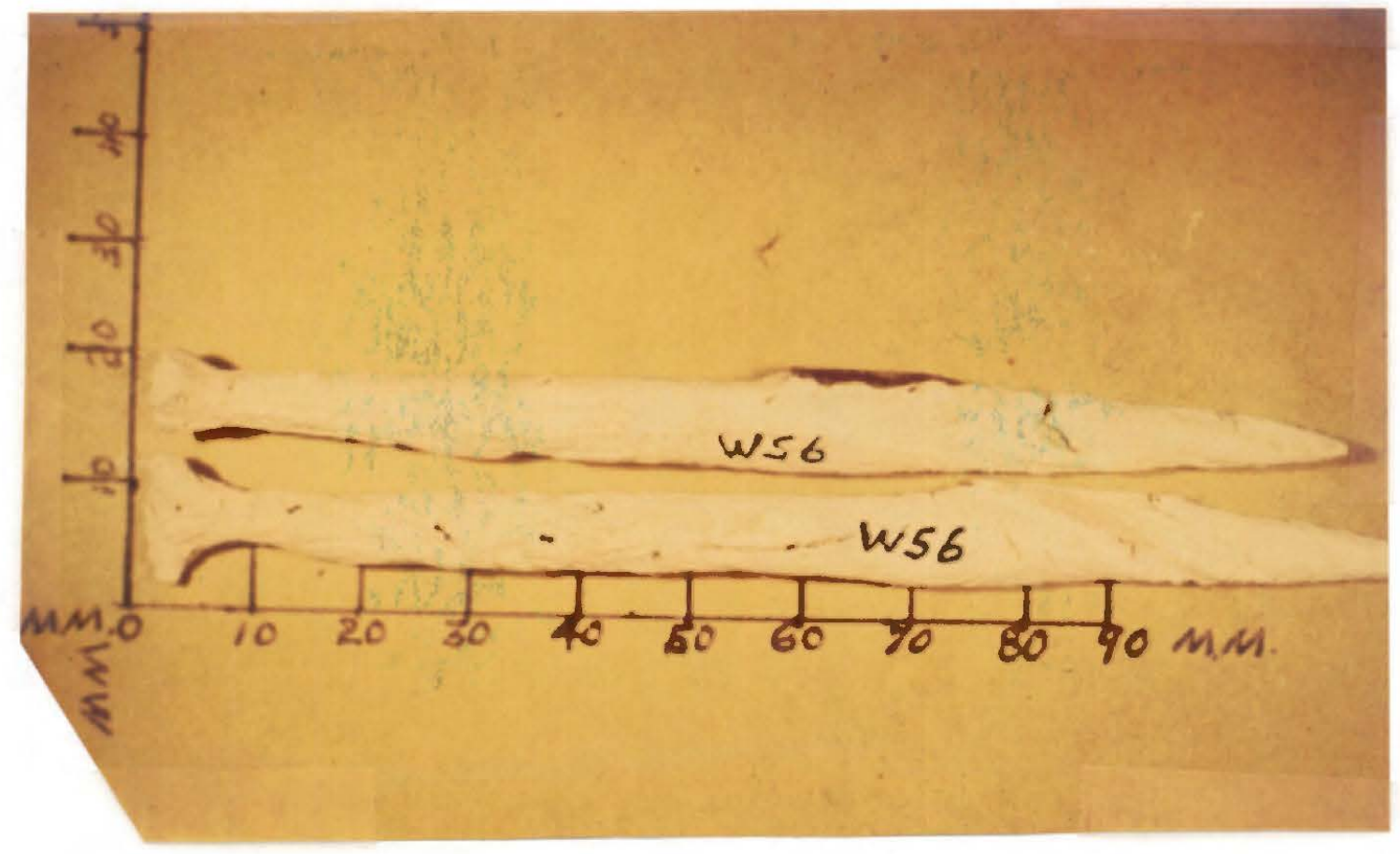

Figure 6. Marine shell beads from Burial 16 at the W-S site.

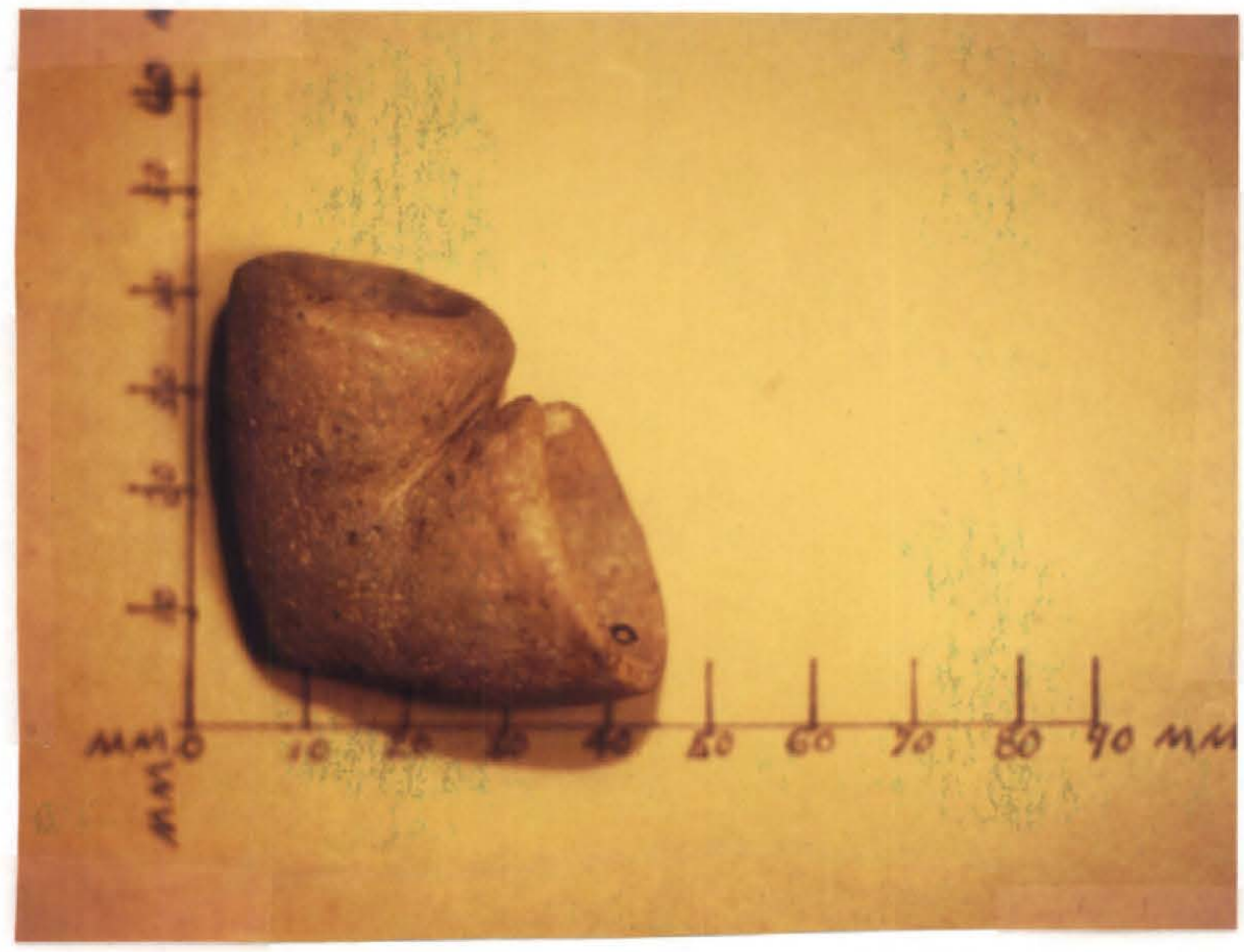

Figure 8. Elbow pipe from a burial at the W-S cemetery. 


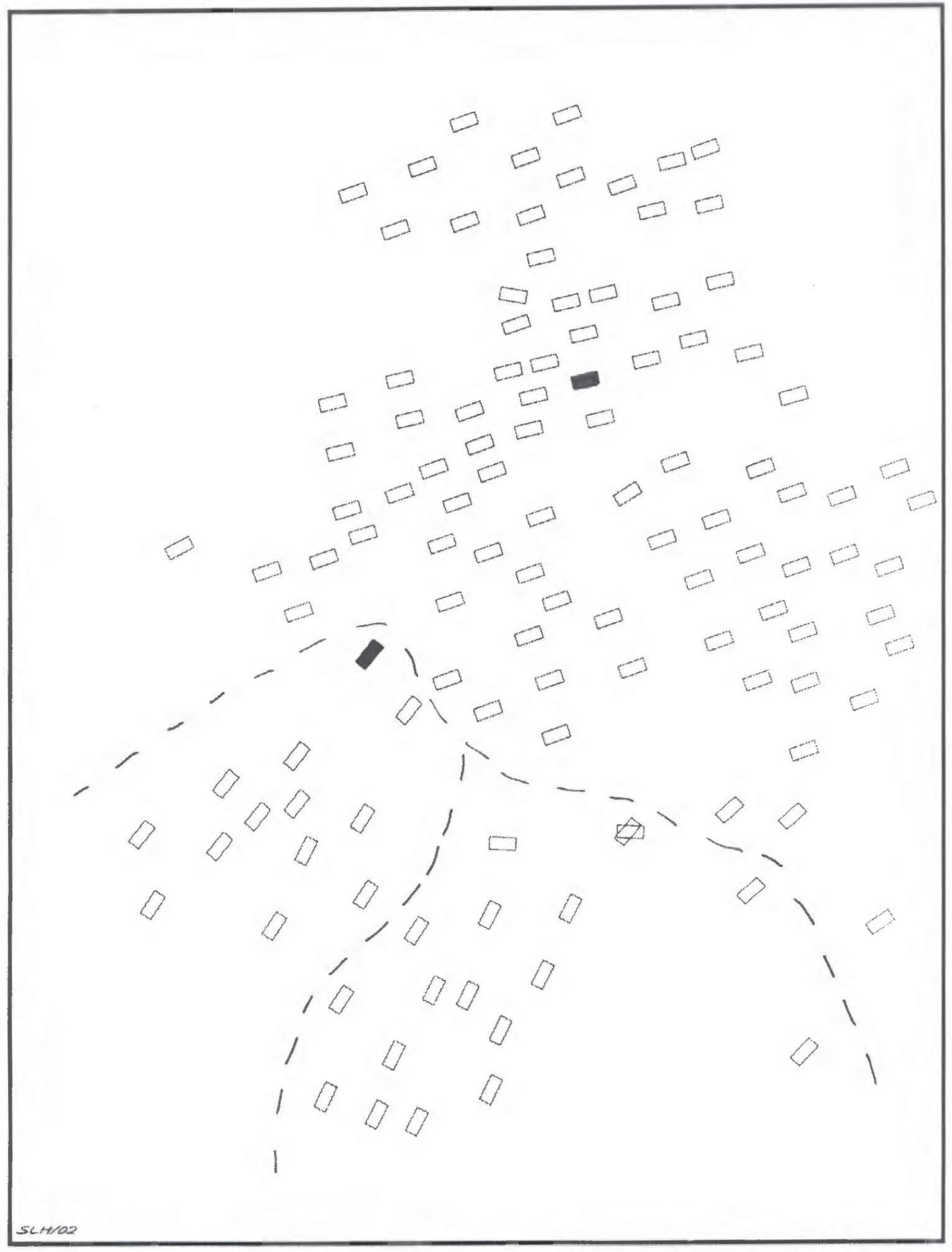

Figure 7. Burials with ear spools at the W-S cemetery (solid black graves). The Phase 1 burial also has marine shell beads. 


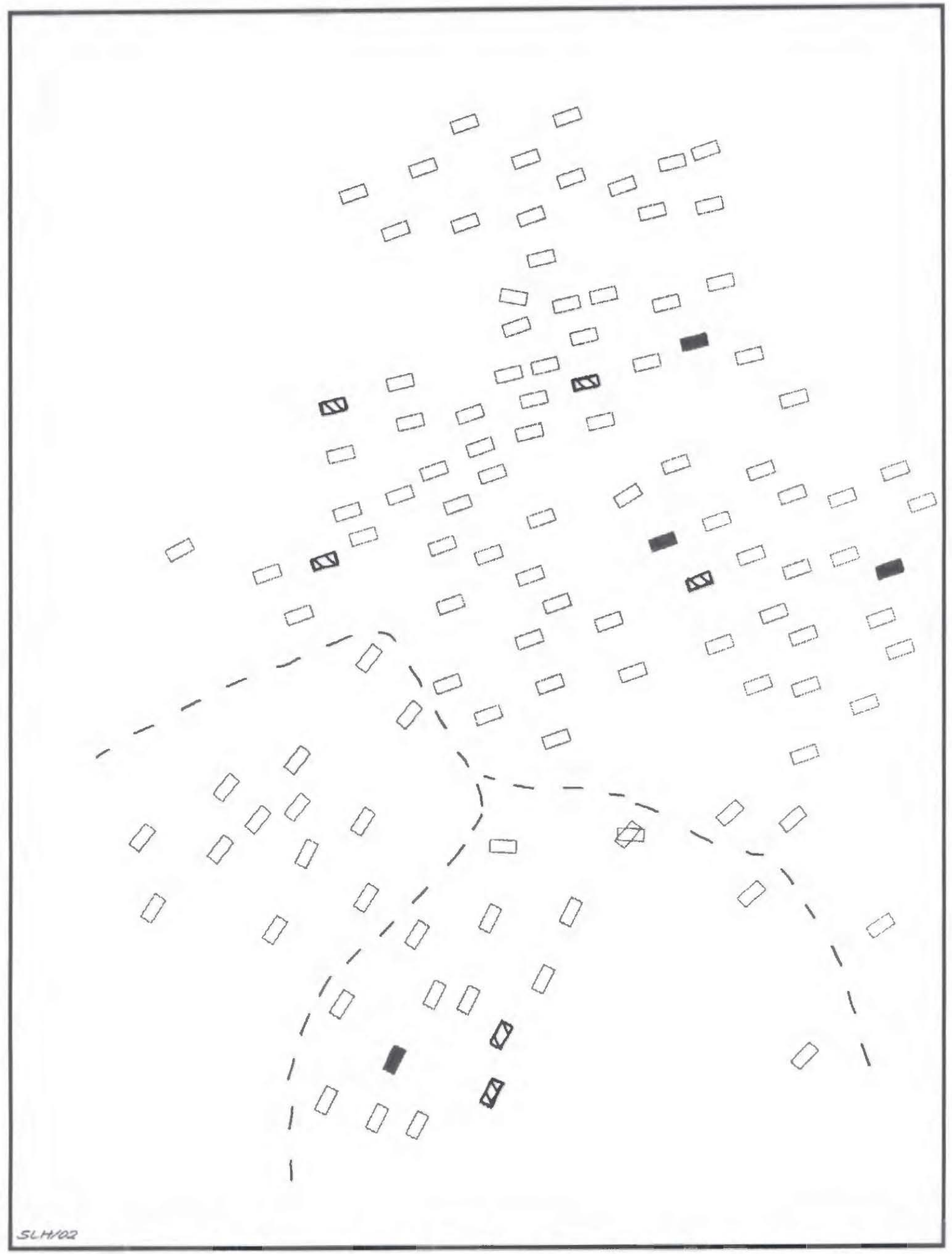

Figure 9. Burials with large chipped blades (solid black graves) and ceramic pipes (hatched graves) 


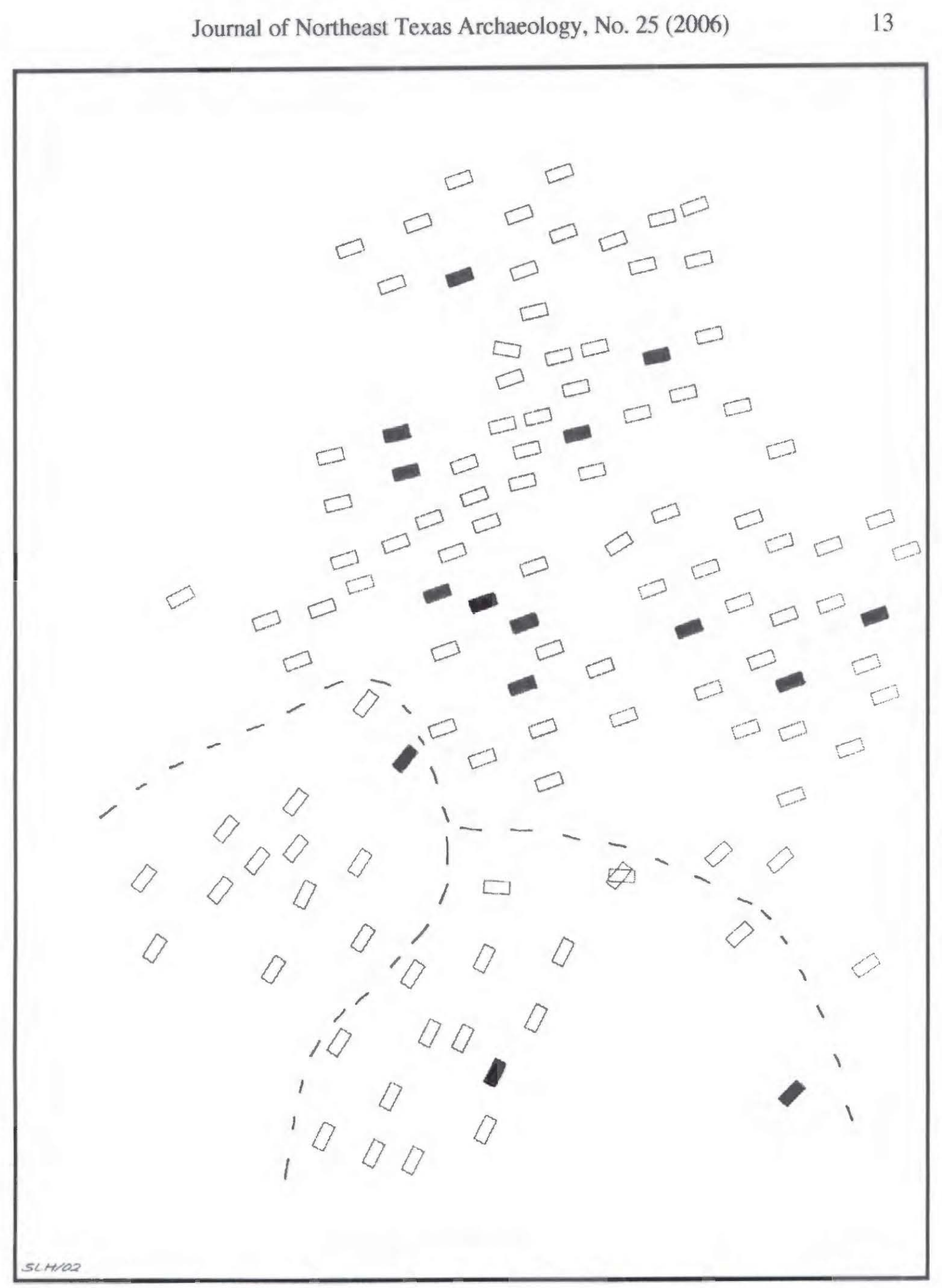

Figure 10. Burials at the W-S site with celts (solid black graves). 
motif-usually seen in post-A.D. 1600 contexts - are present in each cemetery area. However, other late engraved types and utility wares are most frequent in the Phase 3 cemetery area (Figure 11). This includes Simms Engraved and Taylor Engraved vessels, Cass Appliqued jars, double-bottle engraved forms, inverted rim bowls decorated with engraved semi-circles (cf. Womack Engraved), and a double-tiered engraved vessel with suspension holes. This vessel form (complete with double rows of suspension holes) may be a variety of Natchitoches Engraved (see Weinstein et al. 2003: 285, 289). Similar vessels have been documented from the J. M. Riley site (4IUR2), and from two late Titus phase sites in the Gum Creek area of the Little Cypress Creek basin that probably date from ca. A.D. 1670-1700 or thereabouts (Perttula 2006). Based on the occurrence of these distinctive vessels in the Phase 3, I suspect that the last use of the W-S cemetery by Titus phase Caddo peoples took place in the last quarter of the $17^{\text {th }}$ century. No European trade goods were recovered in any of the W-S burials, and thus it appears to be the case that this cemetery (and probably this part of the Big Cypress Creek basin) was abandoned before any sustained contact between the Caddo and Europeans.

In the earliest use of the cemetery (Phase 1 and 2), the burials were oriented in northeast-southwest rows (see Figure 1). There are 30 burials in this area. The remainder of the younger burials in the cemetery (Phase 3 ) are in rough and closely-packed eastwest aligned rows (see Figure 1). The youngest Phase 3 burials at the W-S site include 88 individual graves. Given the limited amount of time that must be represented by the Phase 3 burials - probably only one or two generations - and the limited amount of time that the Caddo cemetery was used in all three phases, the internal structure of the W-S cemetery provides evidence of a significant increase in the number of burials after ca. A.D. 1650/1670. Either the mortality rate of the Caddo communities that used the cemetery increased dramatically at this time, or there was a profound change in mortuary practices and a greater use of community cemeteries by late Titus phase groups. This increased mortality is probably related to a major demographic decline among Titus phase Caddo groups populations in this part of the Big Cypress Creek basin in the last quarter of the $17^{\text {th }}$ century.

Although no bioarchaeological information is available on the age and sex of any of the W-S burials, the creation of this large cemetery, and the regular accompaniment of each burial with personal items and other funerary artifacts, can be employed to speculate about the broader social implications of the W-S Caddo burials. First, the formal existence of an area "used exclusively for the dead" (Goldstein 1980:8) suggests that the Caddo society that developed and used the W-S community cemetery had corporate groups (i.e., extended families linked by kinship) organized by lineal descent (see also discussion in Rogers et al. 2003:21-22). Second, these lineages would have been led by individuals of social distinction, most likely adult males, and third, kinship linkages probably dominated the social organization of the Caddo communities that used the W-S cemetery. 


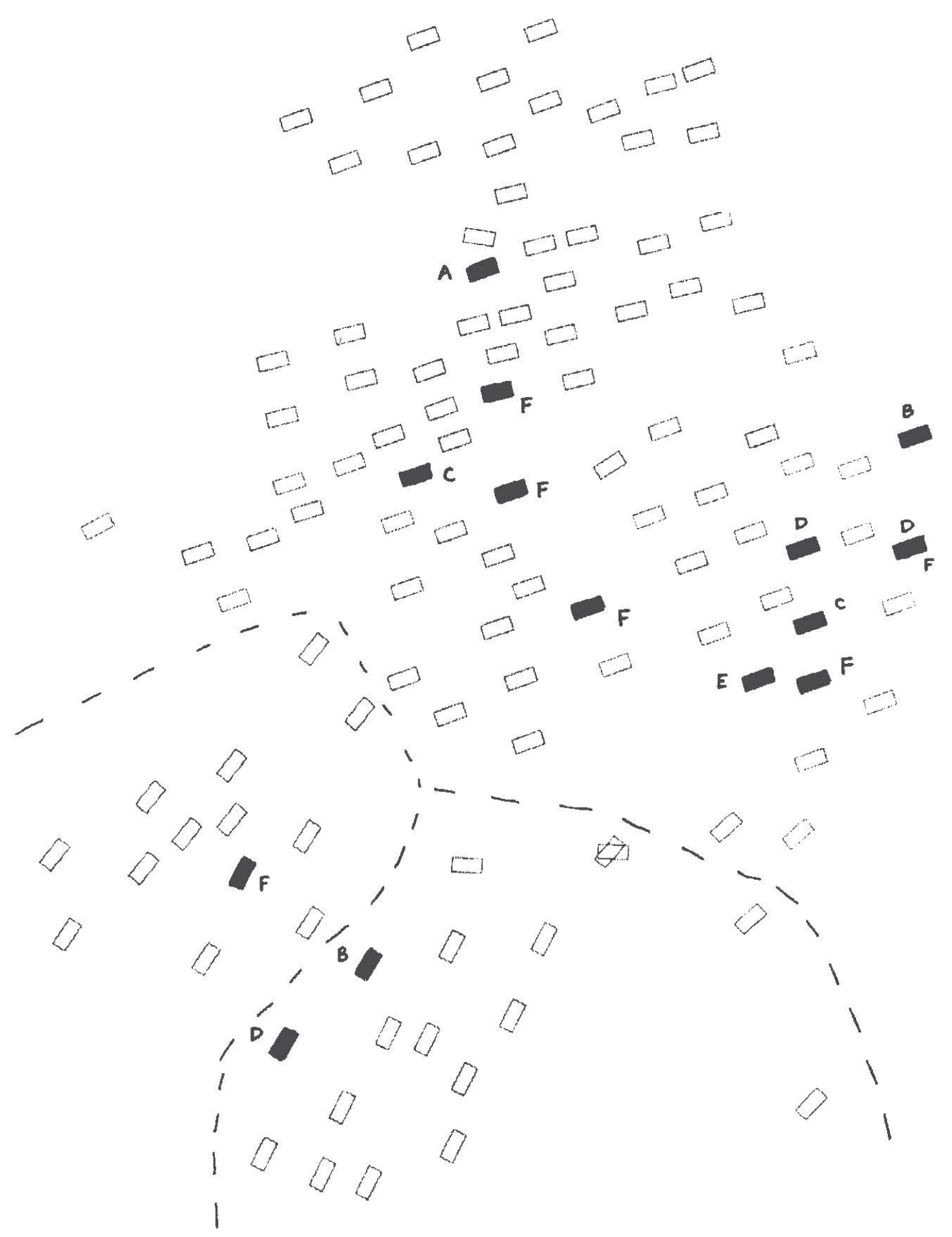

Figure 11. Distribution of unusual and late Titus phase vessels in individual burials (solid black graves. $\mathrm{A}=$ double-ticred vessel; $\mathrm{B}=$ double bottle; $\mathrm{C}=$ Cass Appliqued; $\mathrm{D}=$ Simms Engraved; $\mathrm{E}=$ inverted rim bowl (cf. Womack Engraved) with semi-circles; $\mathrm{F}=$ ='Taylor Engraved. 
Furthermore, Caddo individuals of social distinction would probably have a greater abundance and diversity of associated funerary objects, which would constitute evidence of their social prestige within a specific lineage or group of lineages. Four burials at the W-S cemetery are identified as Caddo individuals of social distinction or prestige: one burial (Burial 16) in Phase 1, two burials (Burials 8 and 90) in Phase 2, and Burial 47 in Phase 3 (Figure 12). These individuals have many arrow points, numerous pottery vessels, celts, ceramic pipes, ear spools, or shell beads (Burial 16). Burial 16 may be the paramount head of the founding Phase 1 lineage. Finally, with few exceptions (i.e., Galt bifaces, shell beads, and ear spools, see Figures 7 and 9), the artifacts placed with the suspected socially prestigious individuals are no different than those funerary offerings placed in the graves of the rest of the Caddo population at the W-S site. All these likely facts point to a late $17^{\text {th }}$ century Caddo society with limited hierarchical ranking or social stratification, but one where prestige and power was held in the hands of specific individuals and lineages.

\section{Acknowledgments}

Thanks to Sandra Hannum for preparing the W-S cemetery base map. Robert L. Turner allowed me to make copies of slides he had of the Ralph Nicholas collection. Finally, I appreciate Carolyn Spock permitting me to access the Ralph Nicholas notes and collections at the Texas Archeological Research Laboratory, The University of Texas at Austin.

\section{References Cited}

Goldstein, L. G.

1980 Mississippian Mortuary Practices: A Case Study of Two Cemeteries in the Lower Illinois Valley. Scientific Papers No. 4. Northwestern University Archaeological Program, Evanston.

Perttula, T. K.

2006 A Study of the Buddy Jones Collection from Northeast Texas Caddo Sites. Special Publication No. 6. Friends of Northeast Texas Archaeology, Pittsburg and Austin.

Perttula, T. K. (editor)

2005 Archeological Investigations of the Pilgrim's Pride Site (4ICP304), a Titus Phase Community in the Big Cypress Creek Basin, Camp County, Texas. 2 Vols. Report of Investigations No. 30. Archeological \& Environmental Consultants, LLC, Austin. 


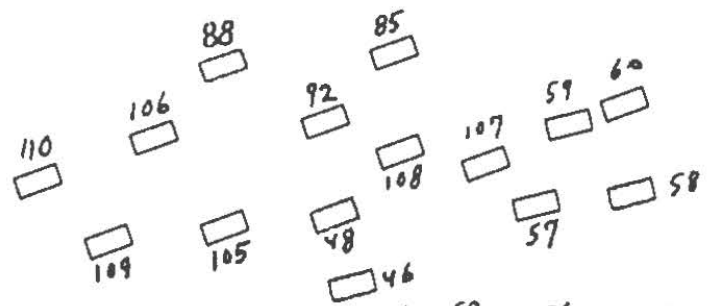

$$
\begin{aligned}
& 60 \square \square 5056 \square 54 \\
& 68 \square_{84}^{52} \square_{51}^{55}
\end{aligned}
$$

Phase 3
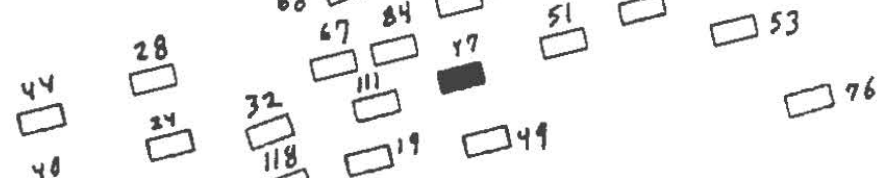

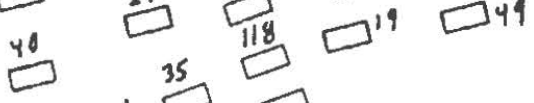

$39 \square_{32}^{41}$<smiles>[C+]1[C+]=CC=C1</smiles>

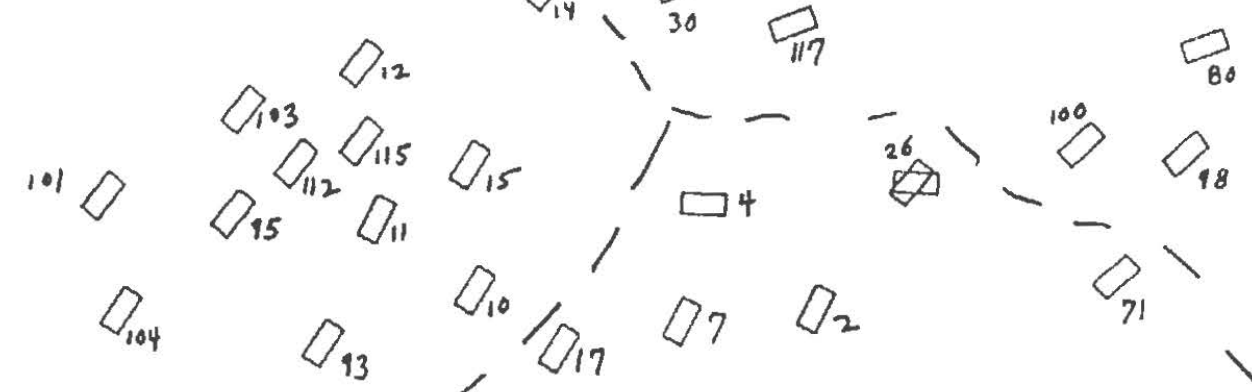

Phase 2

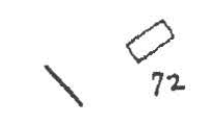

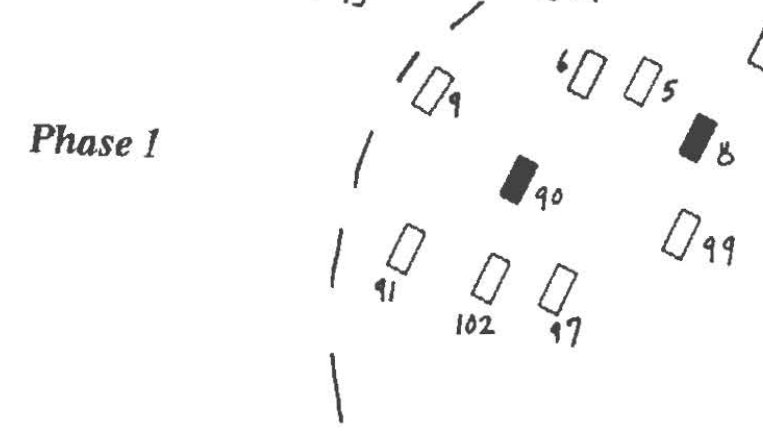

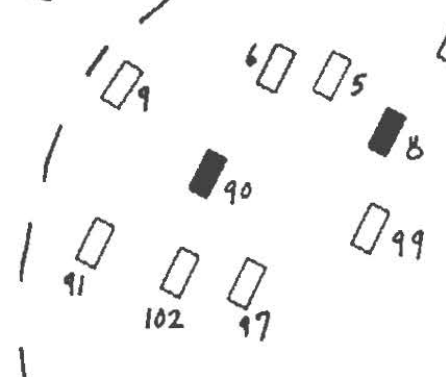
$D_{3}$

Figure 12. Burial locations of socially prestigious Caddo individuals in the Phase 1,2, and 3 cemeteries at the W-S sitc (41TT741). 
Rogers, R., M. B. Cliff, T. K. Perttula, G. Rutenberg, S. Victor, P. Dering, and M. Malainey

2003 Excavations at the Alex Justiss Site, 4ITT13, Titus County, Texas. Archeological Studies Program Report No. 36. Texas Department of Transportation, Austin.

Thurmond, J. P.

1990 Archeology of the Cypress Creek Drainage Basin, Northeastern Texas and Northwestern Louisiana. Studies in Archeology 5. Texas Archeological Research Laboratory, The University of Texas at Austin.

Weinstein, R. A., D. B. Kelley, and J. W. Saunders (editors)

2003 The Louisiana and Arkansas Expeditions of Clarence Bloomfield Moore. University of Alabama Press, 'Tuscaloosa. 